\title{
SMART KAMPUNG SEBAGAI WUJUD KEMAJUAN SISTEM ADMINISTRASI DAN MANAJEMEN DI DESA KETAPANG, KECAMATAN KALIPURO, KABUPATEN BANYUWANGI
}

\author{
Retno Wulan Sekarsari \\ Program Studi Ilmu Administrasi Publik, Fakultas Ilmu Administrasi, Universitas Islam Malang \\ retnowulansekarsari@gmail.com \\ Tedy Winarno \\ Program Studi Ilmu Administrasi Publik, Fakultas Ilmu Administrasi, Universitas Islam Malang
}

\begin{abstract}
Abstrak
Tujuan dari penelitian ini adalah untuk mengetahui sistem pelaksanaan Program "Smart Kampung” di desa Ketapang, dan cara dalam mempublikasikan Program "Smart Kampung" ke seluruh daerah di Indonesia. Program pelayanan publik dan peningkatan kualitas SDM yang berbasis IT dengan nama "Smart Kampung" merupakan sebuah inovasi yang di lahirkan oleh Pemerintah Kabupaten Banyuwangi program ini merupakan wujud dari komitmen Pemerintah Kabupaten Banyuwangi untuk mendekatkan pelayanan publik ke tingkat yang paling mudah untuk di jangkau oleh masyarakat di Banyuwangi, karena sebagian besar masyarakat Banyuwangi tinggal jauh dari kota sebagai basis atau pusat pemerintah maka Pemerintah Kabupaten Banyuwangi menjadikan Kantor Desa sebagai basis pelayanan publik yang terintegrasi langsung dengan Pemerintah Kabupaten sehingga selain mempermudah masyarakat sekaligus untuk menyadarkan masyarakat tentang pentingnya IT. Selain sebagai sarana peningkatan pelayanan publik Program Smart Kampung juga sebagai sarana meningkatkan kualitas SDM dan ekonomi rakyat, dimana pemerintah desa dituntut untuk bisa memberdayakan potensi desanya. Ada beberapa cara yang dilakukan baik oleh Pemerintah Kabupaten Banyuwangi dan desa-desa Smart Kampung untuk mensosialisasikan program ini, penyampaian pada seminar-seminar, pertemuan antar kepala daerah, sampai memanfaatkan sosial media untuk berbagi ceritapun dilakukan, dengan harapan daerah-daerah di Indonesia yang memilik masalah yang sama dengan banyuwangi bisa menerapkan Program Smart Kampung sehingga cita-cita untuk meratakan tingkat kesejahteraan di desa-desa di seluruh Indonesia bisa dicapai.
\end{abstract}

Kata Kunci: Smart Kampung, Sistem Administrasi, Manajemen, Pelayanan Publik.

\begin{abstract}
The objective of this research is to learn about the implementation system of "Smart Kampung" Program at Ketapang Village and its methods of publication to all over Indonesia.This IT-based public service and human resource enhancement program, called "Smart Kampung", is an innovation made by the District Government of Banyuwangi. This program represents the commitment of the district government to bring public service to the most accessible level for the people of Banyuwangi. Since most of them live far from the urban area, which is the governance base or center, the District Government of Banyuwangi set village offices as the centers of public service directly integrated with the District Government. By doing so, the District Government facilitates the society and make them aware of the importance of IT. In addition to being a facility to enhance public service, Smart Kampung Program can also serve as a facility to improve the quality of human resources and the people's economy, as the village governments are required to empower their respective village's potentials. There are a number of ways utilized by the District Government of Banyuwangi and Smart Kampung villagesto socialize this program, such as information sharing in seminars, local leaders meeting, and social media. By doing so, they hope they can inspire regions with similar issues to implement Smart Kampung Program so that the goal to have equal welfare level in all villages in Indonesia can be achieved.
\end{abstract}

Keywords: Smart Kampung, Administration System, Management, Public Service.

\section{PENDAHULUAN}

Apa yang ada di benak kita ketika mendengar kata "kampung"? tentu pikiran kita langsung terpusat pada suatu tempat yang jauh dari keramaian, terpencil, dengan akses yang sulit dijangkau. Suatu tempat yang mungkin terabaikan, tak mendapat perhatian yang layak dari para pemimpin yang berkuasa. Sejenak pikiran kita menerawang kepada masyarakat penghuni kampung yang hidupnya masih terbelakang, karena jauh dari peradaban.

Tapi separah itukah konotasi istilah "kampung" dalam pandangan kita? Rasanya kita terlalu berlebihan dalam menilai suatu tempat bernama "kampung", karena ternyata tidak sedikit kampung yang sangat maju, bahkan kemajuan yang dicapai itu melebihi apa yang terlintas di alam pikir kita. 
Jurnal ini akan mengangkat tema tentang kemajuan Administrasi dan Manajemen di tingkat desa yang lokasinya jauh dari perkotaan dengan judul "Smart Kampung, Wujud Kemajuan Administrasi dan Manajemen di Desa Karanganyar". Ini juga merupakan bukti bahwa konotasi desa tidak seburuk yang di bayangkan, bahkan bisa dikatakan sangat baik.

Administrasi adalah keseluruhan proses kerjasama antara dua orang manusia atau lebih yang didasarkan atas rasionalitas tertentu untuk mencapai tujuan yang telah ditentukan sebelumnya (Siagian, 2016). Ada beberapa hal yang terkandung dalam definisi di atas, yaitu: pertama, administrasi sebagai seni adalah suatu proses yang diketahui hanya permulaanya sedang akhiranya tidak diketahui. Kedua, administrasi mempunyai unsur-unsur tertentu, yaitu adanya dua manusia atau lebih, adanya tujuan yang hendak dicapai, adanya tugas-tugas yang harus dilaksanakan, adanya peralatan untuk melaksanakan tugas-tugas itu. Kedalam golongan peralatan dan perlengkapan termasuk pula waktu, tempat, peralatan materi serta sarana lainya. Ketiga, bahwa administrasi sebagai proses kerjasama bukan merupakan hal yang baru karena ia telah timbul bersama-sama dengan timbulnya peradaban manusia. Tegasnya, administrasi sebagai seni merupakan suatu fenomena sosial. Sedangkan manajemen dapat didefinisikan dari dua sudut pandang, yaitu sebagai proses penyelenggaraan berbagai kegiatan dalam rangka penerapan tujuan dan sebagai kemampuan atau keterampilan orang yang menduduki jabatan manajerial untuk memperoleh sesuatu hasil dalam rangka pencapaian tujuan melalui kegiatan-kegiatan orang lain. Dengan demikian, dapat dikatakan bahwa manjemen merupakan inti dari administrasi karena memang manajemen merupakan alat pelaksana utama administrasi.

Dari pembahasan diatas dapat disimpulkan bahwa administrasi dan manajemen merupakan bagian yang tidak bisa dipisahkan atau bisa dikatakan sebagai satu kesatuan dalam proses pelayanan publik. Baik atau buruknya pelayanan terhadap masyarakat tergantung pada proses Manajemen itu sendiri, ketika manajemen yang jalankan baik, maka akan berbanding lurus dengan sistem administrasinya dan hasilnya pelayanan publik yang di hasilkan juga akan baik.

Smart Kampung merupakan program inovasi yang digagas oleh Bupati Banyuwangi yakni Abdullah Azwar Anas. Program ini muncul di karenakan beberapa faktor antara lain:

1. Banyuwangi merupakan kabupaten terluas di pulau Jawa, sehingga menyebabkan akses dari desa ke pusat pemerintahan sangat jauh.

2. Semakin berkembangnya teknologi inforrmasi yang menyebabkan adanya tuntutan untuk memanfaatkanya semaksimal mungkin.
3. Rendahnya kualitas Sumber Daya Manusia (SDM) terutama di desa-desa yang jauh dari kota.

Faktor-faktor diataslah yang kemudian mendasari munculnya program Smart Kampung. Program ini seakan menjawab tantangan dari pemerintah pusat agar daerahdaerah di Indonesia berlomba-lomba dalam memberdayakan masyarakatnya terutama yang ada di desa-desa. Sesuai dengan cita-cita Presiden Jokowi bahwa pembangunan yang ada di Indonesia harus di mulai dari desa baru kemudian menuju kota. Pembahasan di paper ini pun akan lebih terfokus pada teknis pelaksanaan Smart Kampung dan publikasinya, dan pada kesempatan kali ini penulis akan mengambil salah satu desa yang sudah menerapkan Smart Kampung yakni Desa Ketapang Kecamatan Kalipuro Kabupaten Banyuwang yang notabene merupakan salah satu pilot project pengembangan program Smart Kampung. Rumusan masalah dalam penelitian ini adalah: Bagaimana sistem pelaksanaan Program "Smart Kampung" di desa Ketapang? dan Bagaimana cara dalam mempublikasikan Program "Smart Kampung” di Desa Ketapang ke daerahdaerah yang lain?

\section{METODE}

Penelitian ini menggunakan jenis penelitian deskriptif - kualitatif. Bogdan dan Taylor dalam Moleong (2002:3) mendefinisikan metode kualitatif sebagai prosedur penelitian yang menghasilkan data deskriptif berupa kata-kata tertulis atau lisan dari orang-orang dan perilaku yang dapat diamati. Peneliti menggunakan beberapa untuk mengumpulkan data (Arikunto, 1990:134), yakni: studi kepustakaan dan studi lapangan.

Instrumen penelitian ini digunakan untuk mensistematiskan pengumpulan data (Mayer and Greenwod, 1984:399). Adapun instrumen yang valid dan reliable (Sugiyono, 2005:110) pada penelitian ini meliputi: peneliti sendiri, pedoman wawancara, dan catatan lapangan. Analisis data menggunakan konsep Miles dan Huberman (1992:18-21) yang terdiri dari: reduksi data, penyajian data, kesimpulan, dan verifikasi.

\section{HASIL DAN PEMBAHASAN}

1. Sistem sistem pelaksanaan Program "Smart Kampung"di Desa Ketapang

Smart Kampung merupakan sebuah program pelayanan publik yang digagas oleh Pemerintah Kabupaten Banyuwangi berbasis IT. Program ini dibuat menyesuaikan kondisi masyarakat yang ada di Banyuwangi, mayoritas masyarakat Banyuwangi yang tinggal di desa terkesan sulit ketika ingin mengurus keperluan surat menyurat terkait dengan Pemerintahan, 
mengingat Banyuwangi merupakan kabupaten terluas di Jawa mengakibatkan akses dari Desa ke Kota atau pusat Pemerintahan sangat jauh, permasalahan ini yang menyebabkan pelayanan publik bisa dibilang lamban mengingat proses pengurusan juga memakan waktu yang tidak sebentar. Kondisi inilah yang menginspirasi Bupati Banyuwangi Abdullah Azwar Anas untuk terus berinovasi dalam menghadirkan pelayanan publik yang bisa memudahkan masyarakat, maka munculah ide untuk memanfaatkan teknologi yang kini seakan tidak bisa dipisahkan dari masyarakat untuk meningkatkan pelayanan publik, inilah yang melatar belakangi munculnya program "Smart Kampung". Program pelayanan publik yang tidak hanya concern pada pelayanan saja, tetapi juga fokus terhadap peningkatan fungsi desa dan SDM.

Berdasarkan berita dari website daerah, sampai saat ini sudah ada lebih dari 80 Desa di Banyuwangi yang sudah menetapkan dirinya sebagai Smart Kampung dari 176 Desa yang ada. Tidak semua desa bisa langsung menerapkan program ini, desa yang ingin menjadikan desanya sebagai Smart Kampung setidaknya harus memenuhi 7 kriteria yang sudah di tetapkan oleh Pemerintah Kabupaten yaitu pemberdayaan ekonomi, pelayanan kesehatan, pengembangan pendidikan dan senibudaya, peningkatan kapasitas SDM, integrasi pengentasan kemiskinan, dan informasi hukum.

Dengan adanya 7 kriteria diatas pemerintah desa dituntut untuk berlomba-lomba dalam memunculkan inovasi-inovasi baru sehingga 7 kriteria tersebut bisa dipenuhi. Pemerintah desa tidak bekerja sendiri karna Pemerintah Kabupaten tentu akan terus mendorong dan memfasilitasi Pemerintah Desa untuk produktif dalam menghadirkan pelayanan yang baik sehingga target Pemerintah Kabupaten Banyuwangi untuk menjadikan seluruh desa menjadi Smart Kampung pada awal tahun 2018 bisa terwujud.

Salah satu desa yang dianggap sukses dalam menjalankan Program Smart Kampung adalah Desa Ketapang Kecamatan Kalipuro Banyuwangi. Desa yang di komandani oleh H. Slamet Kasihono, S.Ag ini dibilang berhasil dalam memunculkan beberapa inovasi-inovasi terkait dengan pelayanan publik juga dengan peningkatan SDM warganya, ada beberapa program inovasi yang di terapkan oleh pemerintah Desa Ketapang antara lain :

a. SIMADe (Sistem Manajemen Desa)

Program SIMADe atau sistem manajemen desa merupakan program inovasi pelayanan publik yang di jalan oleh Desa Ketapang, merupakan program pengolahan data kependudukan masyarakat Desa Ketapang, aplikasi SIMADe memungkin data kependudukan mulai dari pekerjaan, pendidikan, agama, dan lain sebagainya terintregasi dengan baik, hal inilah yang kemudian memudahkan Pemerintah Desa dalam melakukan pelayanan publik, semua data tentang warga desa bisa dilihat di aplikasi ini terperinci secara individual.

Dengan aplikasi SIMADe pula pelayanan publik seperti pembuatan surat menyurat menjadi mudah dan efisien, pengurusan surat seperti SKCK, SPM, pembuatan KTP yang awalnya membutuhkan waktu berhari-hari, dengan SIMADes hanya butuh hitungan menit saja surat sudah bisa terbit. Lebih canggih lagi bahwa aplikasi ini mempunyai kemampuan untuk bisa mengupdate data yang masuk melalui surat kelahiran, dengan artian ketika ada bayi yang baru lahir kemudian membuat surat kelahiran di desa, maka secara otomatis data diri tentang bayi tersebut sudah masuk.

Tidak perlu khawatir tentang kevalidan data karena Pemerintah Desa juga terjun langsung dalam mendata warganya, sehingga data yang didapatkan bisa langsung di konfirmasi oleh masyarakat sendiri. Tidak hanya berhenti disitu saja, bahkan jika masyarakat desa yang ingin mengurusi surat-surat tidak bisa datang langsung ke kantor desa masyarakat juga bisa menggunakan layanan sms-center yang langsung tersambung ke server aplikasi SIMADe. Hanya cukup menyebutkan nama dan NIK, warga tinggal menunggu dan mengambilnya nanti ketika sudah jadi. Berbagai pelayanan diatas tentu semata ingin membuat masyarakat bisa menikmati mudahnya mengurus keperluan administrasi dan disamping itu secara tidak langsung program ini membuat masyarakat bisa berfikir dan melek teknologi yang akhirnya bisa meningkatkan kualitas SDM.

b. BUMDes (Badan Usaha Milik Desa)

Jika kita berbicara tentang BUMDes tentu tendensi utamanya adalah Pendapatan Anggaran Desa, karena pada intinya usaha yang dilakukan oleh Pemerintah Desa melalui BUMDes merupakan upaya untuk meningkatkan Pendapatan Desa yang digunakan untuk kebutuhan desa. Hal itulah yang juga dilakukan oleh pemerintah Desa Ketapang untuk bisa memanfaatkan BUMDes sebagai aset yang menyumbang Pendapatan Desa, terbukti melalu serangkaian proses yang cukup panjang akhirnya BUMDes bernama Citra Mandiri milik Desa Ketapang bisa berdiri dan menyumbangkan pendapatan bagi desa, tidak tangung-tanggung dalam 1 tahun keuntungan yang di dapatkan berkisar antar 80-100 juta, hal ini tentu sangat positif dan sangat bermanfaat karna dengan adanya BUMDes tidak hanya meningkatkan Pendapatan Desa tetapi juga sebagai langkah untuk memberdayakan masyarakat desa Ketapang, tidak berlebihan rasanya ketika saya bilang bahwa BUMDes Citra Mandiri tidak hanya berkontribusi pada Pendapatan Desa tetapi juga pemberdayaan terhadap masyarakat karna usaha atau 
bentuk usaha dari Citra Mandiri sendiri ada berbagai macam antara lain:

\section{1) Toserba Desa}

Dalam usaha ini Pemerintah Desa Ketapang juga bekerja sama dengan distributor terkait dengan kesepakatan harga, sehingga harga yang ada di Toserba desa lebih murah dibandingkan dengan di toko biasa, ini dilakukan juga agar masyarakat mendapatkan kepuasan saat berbelanja, bahkan pemerintah desa juga bekerjasama dengan Bulog untuk kebutuhan bahan pokok, tentu ini merupakan suatu hal yang sangat baik ketika Pemerintah Desa tidak hanya berpangku tangan dengan Pemerintahan diatasnya tetapi juga mau membuka diri untuk bekerjasama dengan pihak swasta sekalipun.

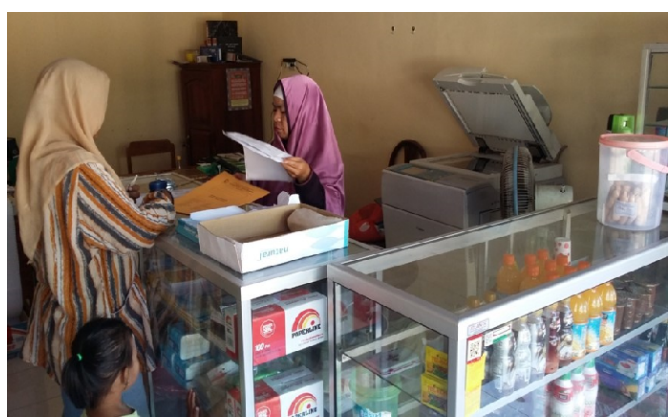

Gambar 1. Toserba (Toko Serba Ada) Desa Ketapang

(Sumber: ketapangbwi.desabanyuwangi.com)

\section{2) Kantin Desa}

Pemerintah Desa Ketapang untuk membuat kantin desa bagi warga yang berkunjung ke kantor desa, sehingga saat ada masyarakat yang hendak mengurus suatu hal atau hanya untuk berkumpul-kumpul bisa menikmati suasan kantor desa yang nyaman dengan fasilitas yang baik pula termasuk kantin desa sehingga Kantor Desa bisa dijadikan pusat kegiatan masyarakat.

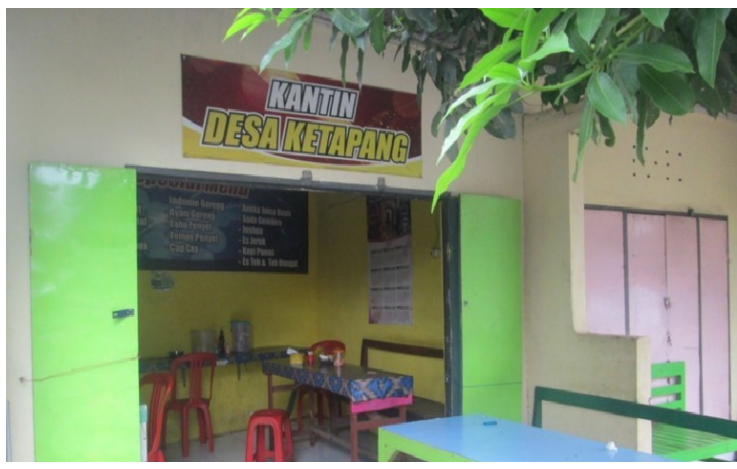

Gambar 2. Kantin Desa Ketapang

(Sumber: ketapangbwi.desabanyuwangi.com)

\section{3) Pasar Tradisional}

Pemerintah Desa Ketapang memanajemen pasar tradisional dengan merombak dan memperbaiki tatanan pasar tradisional. Penataan seperti lahan parkir kemudian tempat pembuangan sampah dan lain sebagainya terus diperbaiki dengan mendengarkan aspirasi dari pembeli dan pedagang sehingga bisa terwujud pasar tradisional rasa modern.

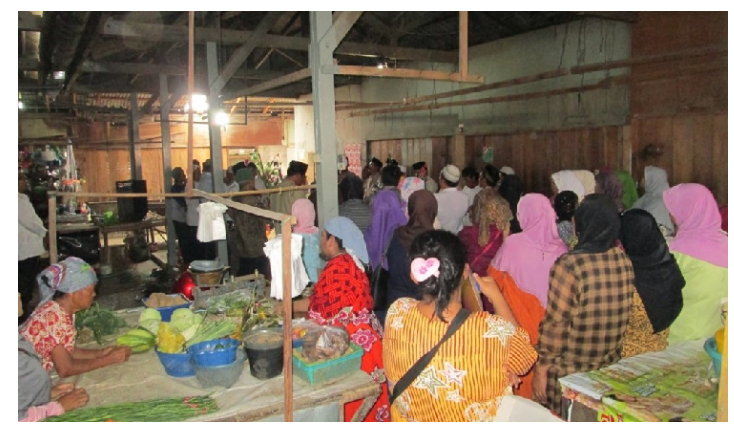

Gambar 3. Pasar Desa Ketapang

(Sumber: ketapangbwi.desabanyuwangi.com)

4) Peternakan Kambing

Di Desa Ketapang mayoritas warganya selain berprofesi sebagai Petani sebagian besar juga sebagai Peternak, yaitu sebanyak 625 orang sehingga pemerintah Desa Ketapang membuat peternakan kambing untuk warganya. peternakan yang di kelola oleh Pemerintah Desa Ketapang, kesejahteraan para buruh ternak bisa terjamin karena mereka bekerja selain dibayar pun juga akan mendapatkan bagian hewan ternak ketika hewan tersebut beranak.

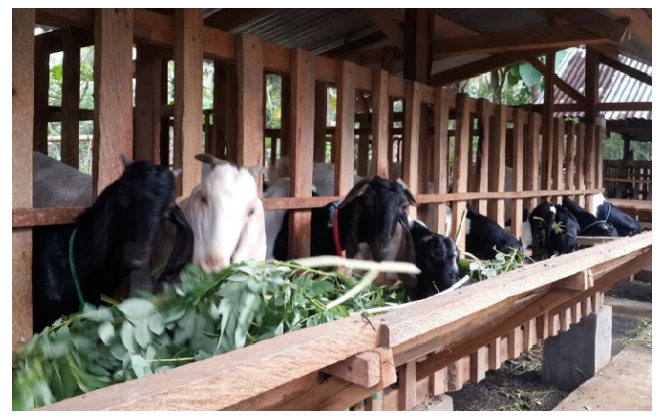

Gambar 4. Peternakan Kambing Desa Ketapang (Sumber: ketapangbwi.desabanyuwangi.com)

\section{5) Pariwisata}

Perlu diketahui bahwa desa Ketapang berbatasan langsung dengan Selat Bali, ini yang kemudian menghadirkan peluang bagi desa untuk memanfaatkan situasi geografis Desa Ketapang, munculah kemudian ide untuk membuat sebuah destinasi pariwisata sekaligus pelestarian lingkungan khusunya biota laut yakni terumbu 
karang, terbukti wisata penanaman terumbu karang ternyata banyak menarik minat wisatawan karna disamping mereka bisa menyelam di bawah laut mereka pun juga merasa ikut andil dalam melestarikan lingkungan.

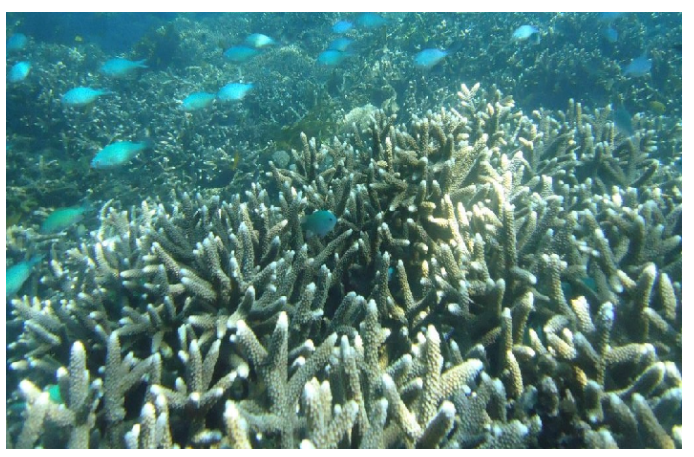

Gambar 5. Pariwisata Desa Ketapang (Sumber: ketapangbwi.desabanyuwangi.com)

\section{6) Desa Literasi}

Ada satu lagi program pengembangan sumber daya manusia yang digagas oleh Pemerintah Desa Ketapang yakni Desa Literasi, bahkan tidak hanya menjadi sekedar Desa Literasi saja, bahkan Desa Ketapang juga ditetapkan sebagai pilot project Desa Literasi oleh Rumah Literasi Banyuwangi (RLB). Hal ini merupakan bentuk komitmen Desa Ketapang untuk terus meningkatkan kualitas SDM warganya. Ada beberapa program dan kegiatan yang diadakan oleh Desa Literasi ketapang salah satunya program satu Rumah Literasi untuk satu RW, sehingga di setiap RW memilik rumah bacanya masing-masing. Selain itu Pemerintah Desa yang bekerja sama dengan RLB juga rutin mengadakan Literasi di pinggir jalan dan di tempat-tempat keramaian, hal ini semata dilakukan untuk menarik simpatik dari warga sehingga mau bergabung dengan mereka.

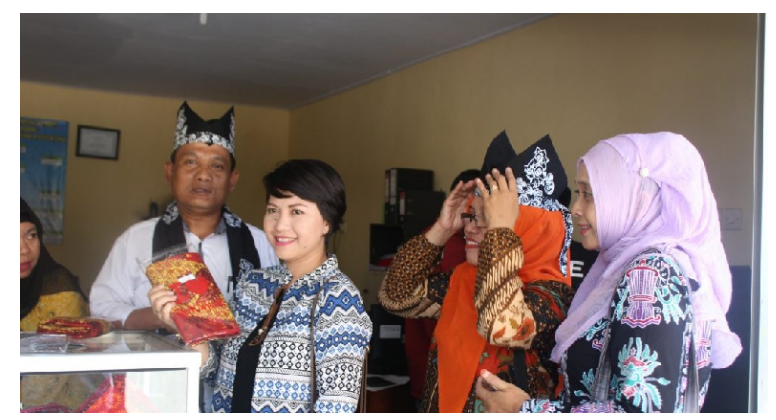

Gambar 6. Desa Ketapang sebagai Desa Literasi (Sumber: ketapangbwi.desabanyuwangi.com)

Yang menarik bahwa tidak hanya para pelajar dan anak-anak saja yang menjadi sasaran dari desa literasi ketapang, tetapi juga orang tua. Salah satu wujud pemberdayaan terhadap orang tua untuk membaca adalah kegiatan Sekolah Orang Tua (SOT). Program ini ditujukan kepada orang tua (lansia) yang ada di Desa Ketapang. Kegiatan ini diadakan di salah satu rumah baca yang ada di Desa Ketapang yakni Rumah Baca Sahabat Kecil. Diadakannya Desa Literasi Ketapang yang bekerja sama dengan Rumah Literasi Banyuwangi oleh pemerintah desa adalah upaya untuk membuat masyarakat Desa Ketapang gemar membaca dan siap menghadapi persaingan global.

2. Caranya Mempublikasikan Program "Smart Kampung" ke daerah-daerah lain

Jika melihat pembahasan tentang sistem pelaksanaan Smart Kampung diatas, patut rasanya daerahdaerah yang memilik kesamaan karakteristik permasalahan dengan Kabupaten Banyuwangi juga menerapkan program ini. Sebenarnya sudah ada banyak kabupaten/kota yang datang ke Desa Ketapang untuk melaksanakan study banding terkait dengan keberhasilan Program Smart Kampung. Karena disadari atau tidak program ini ternyata sesuai dengan salah satu Nawacita Presiden Jokowi yakni pembangunan dari desa ke kota, artinya program ini memang sangat cocok dengan sebagian besar wilayah di Indonesia yang mengalami permasalahan kesenjangan pembangunan yang dikarenakan jarak dan waktu.

Apalagi kalau kita bicara wilayah bagian timur Indonesia yang sebagian besar perkembangan IT masih belum secanggih atau secepat di Pulau Jawa. Program ini bisa dikatakan sesuai untuk bisa lebih mengenalkan IT ke pelosok negeri. Ada banyak hal yang dilakukan oleh Pemkab Banyuwangi dan Pemerintah Desa Ketapang untuk menggaungkan Smart Kampung, yaitu mempromosikan program ini di berbagai kesempatan ketika berkunjung ke daerah lain.

Pemerintah Kabupaten Banyuwangi dan Pemerintah Desa Ketapang pun juga memperkenalkan program Smart Kampung di desa ini lewat media sosial, seperti facebook, twitter, instagram, bahkan Pemerintah Desa Ketapang mempunyai channel youtube tersendiri, sehingga tidak hanya orang Indonesia saja yang bisa melihat tetapi juga orang diseluruh dunia bisa melihat betapa cerdasnya pengelolaan adminstrasi dan manajemen yang ada di Desa Ketapang.

Dengan gencarnya inovasi program dan promosi Smart Kampung yang dilakukan pemerintah Kabupaten Banyuwangi, Bupati Abdullah Azwar diundang ke Malaysia untuk memaparkan tentang program ini di depan para pemimpin daerah disana. Yang terbaru adalah Kabupaten Jombang yang membawa rombongan seluruh 
SKPD-nya untuk belajar tentang program Smart Kampung di Desa Ketapang.

\section{PENUTUP}

\section{Simpulan}

Program pelayanan publik dan peningkatan kualitas SDM yang berbasis IT dengan nama "Smart Kampung" merupakan sebuah inovasi yang di lahirkan oleh Pemerintah Kabupaten Banyuwangi program ini merupakan wujud dari komitmen Pemerintah Kabupaten Banyuwangi untuk mendekatkan pelayanan publik ke tingkat yang paling mudah untuk di jangkau oleh masyarakat di Banyuwangi, karena sebagian besar masyarakat Banyuwangi tinggal jauh dari kota sebagai basis atau pusat pemerintah maka Pemerintah Kabupaten Banyuwangi menjadikan Kantor Desa sebagai basis pelayanan publik yang terintegrasi langsung dengan Pemerintah Kabupaten sehingga selain mempermudah masyarakat sekaligus untuk menyadarkan masyarakat tentang pentingnya IT.

Selain sebagai sarana peningkatan pelayanan publik Program Smart Kampung juga sebagai sarana meningkatkan kualitas SDM dan ekonomi rakyat,dimana pemerintah desa dituntut untuk bisa memberdayakan potensi desanya. Beberapa cara yang dilakukan baik oleh Pemerintah Kabupaten Banyuwangi dan desa-desa Smart Kampung untuk mensosialisasikan program ini, penyampaian pada seminar-seminar, pertemuan antar kepala daerah, sampai memanfaatkan sosial media untuk berbagi ceritapun dilakukan, dengan harapan daerahdaerah di Indonesia yang memilik masalah yang sama dengan banyuwangi bisa menerapkan Program Smart Kampung sehingga cita-cita untuk meratakan tingkat kesejahteraan di desa-desa di seluruh Indonesia bisa dicapai.

\section{Saran}

Dari pemaparan pembahasan yang sudah di sampaikan diatas penulis memberikan beberapa saran, yaitu:

1. Penambahan infrastruktur IT diseluruh desa-desa yang ada di Kabupaten Banyuwangi harus terus di tingkatkan agar terget untuk menjadikan seluruh desa di Kabupaten Banyuwangi sebagai Smart Kampung pada tahun 2018 bisa tercapai.

2. Banyak dilakukan kegiatan sosialisasi kepada warga yang desanya akan dijadikan sebagai Smart Kampung juga harus dilakukan secara bertahap agar masyarakat yang awalnya tidak paham dengan teknologi bisa mengerti bagaimana cara memanfaatkan program tersebut.
3. Publikasi program Smart Kampung di media sosial harus terus ditingkatkan mengingat sekarang ini masyarakat tidak bisa lepas dari pengaruh media sosial. Kondisi harus dimanfaatkan semaksimal mungkin oleh Pemerintah Kabupaten Banyuwangi khususnya dan Pemerintah Desa Ketapang untuk terus menggaungkan program ini.

\section{DAFTAR PUSTAKA}

Arikunto, Suharsimi. 1990. Manajemen Penelitian. Jakarta: Rineka Cipta.

Banyuwangikab. (2017 16 Februari), Smart Kampung Banyuwangi: Gerakkan Ekonomi Lokal, Diperoleh 09 Oktober 2017, dari (https://www.banyuwangikab.go.id/beritadaerah/smart-kampung-banyuwangi-gerakkanekonomi-lokal.html).

Ketapangbwi. (2017 02 Maret), Profil Smart Kampung Desa Ketapang, Diperoleh 09 Oktober 2017, dari(http://ketapangbwi.desabanyuwangi.com/).

Koentjaraningrat. 1991. Metode-Metode Penelitian Masyarakat. Jakarta: PT. Raja Grafindo Persada.

Kompasiana.(2016, 02 Juni).Menelisik Banyuwangi : Smart Kampung yang Menginspirasi, Diperoleh 09 Oktober 2017, dari (https://www.kompasiana.com/indriya.purnamasari/m enelisik-banyuwangi-smart-kampung-yangmenginspirasi_558445b4d67a61080b8b4567).

Moleong, Lexy, J. 2002. Metodologi Penelitian Kualitatif. Bandung: PT. Remaja Rosada Karya.

Mayer, Robert R. \& Greenwood, Ernest. 1984. Rancangan Penelitian Kebijakan Sosial. Jakarta: CV Rajawali.

Siagian, P Sondang. 2016. Filsafat Administrasi. Jakarta : PT. Bumi Aksara. 